OOPEN ACCESS

International Journal of Management \& Entrepreneurship Research

P-ISSN: 2664-3588, E-ISSN: 2664-3596

Volume 3, Issue 2, P.No. 84-96, February, 2021

DOI: 10.51594/ijmer.v3i2.211

Fair East Publishers

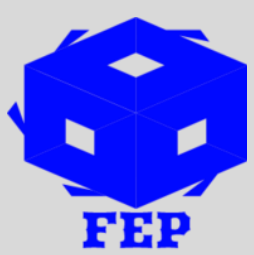

Journal Homepage: www.fepbl.com/index.php/ijmer

\title{
ROLE OF ENTREPRENEUR'S COMPETENCE ON GROWTH OF SMALL AND MEDIUM ENTERPRISES
}

\author{
Dr. Fred GichanaAtandi $\mathrm{PhD}^{1}$
}

${ }^{1}$ Lecturer, Kibabii University, P.O.Box 1699-50200, Bungoma, Kenya. School Of Business, Department Of Business Administration And Management

Corresponding Author: Dr. Fred GichanaAtandi

Corresponding Author Email: fgatandi@kibu.ac.ke

Article Received:15-02-21

Accepted: 28-02-21

Published:05-03-21

Licensing Details: Author retains the right of this article. The article is distributed under the terms of the Creative Commons Attribution-Non Commercial 4.0 License (http://www.creativecommons.org/licences/by-nc/4.0/) which permits non-commercial use, reproduction and distribution of the work without further permission provided the original work is attributed as specified on the Journal open access page.

\begin{abstract}
The study endeavored to determine the role of entrepreneur's competence on growth of small and medium enterprises. The specific objectives of the study were to; establish entrepreneur's competence small and medium enterprises in Bungoma County, examine the growth of small and medium enterprises in Bungoma county and to determine the relationship between entrepreneur's competence and growth of small and medium enterprises. The study used a combination of descriptive, cross-sectional and correlation research designs and data was gathered using a self-administered questionnaire on 201 SMEs. Data was analyzed using descriptive and inferential statistics. The resource-based theory was used to guide this research. The study findings indicated that the grand mean for entrepreneur's competence was low with a mean of 2.23 with a SD of 0.50 . The implications of the findings is that SMEs operators in Bungoma county lack the prerequisite entrepreneurial skills and knowledge affecting their growth save for resource mobilization. It was also found that the grand mean for growth of SMEs was low with a mean of 1.96 and SD of 0.58. The implication of the findings was that SMEs were performing dismally affecting their graduation/transition to the next higher level. The study results also found that there was a significant relationship between entrepreneur's competence and growth of SMEs with p. value 0.000. The study concluded that SMEs should embrace relevant competence skills to enable them operated
\end{abstract}


growth oriented enterprises which can graduate to higher levels thereby contributing to improved social and economic life of the operators and the nation at large. The study recommended that owner managers of SMEs to attend trainings on resource mobilization and innovation so as to acquire adequate resource mobilization and innovation skills and differentiate themselves in the market place to grow their enterprises. The study further recommended that government to put in place entrepreneurship policy to nurture business startups through mentorship, motivation and attitude change as they walk through entrepreneurship journey.

Keywords: Entrepreneur's Competence, Growth, Small and Medium Enterprises

\section{INTRODUCTION}

SMEs in Kenya serve as live blood to the poor; create employment opportunities, generate income and contribute to economic growth (Mukoma \&Masini, 2015). Despite the SMEs importance in Kenya, 2.2 million SMEs have shutdown in the last five years (KNBS report, 2016). According to this report most of the closed businesses were mostly those in wholesale and retail trade as well as repair of motor vehicles and motor cycles sector which accounted for $73 \%$ of the total closure. Mostly these SMEs closed at the age of 3.8 years. $46.3 \%$ of SMEs closed without even the first year of operation ending (Economic survey report, 2017). SMEs in Kenya do not grow into large enterprises (Githire \& Muturi, 2015). This failure of SMEs in Kenya may lead to social crimes with high probability of insecurity, low liquidity in the economy and losses of jobs and this result to threatening economic development and Kenya realization of vision 2030 (Janet \&Ngugi ,2014). Studies by Ahmad et al. (2010) found that entrepreneurial competencies predict the success of SMEs in Malaysia. The study of Bosire and Nzaramba (2013) in their findings concludes that development of entrepreneurial skills could serve as a measure for improving the self reliant of startups and established entrepreneurs. Similarly, they found that entrepreneur's success depended on entrepreneurial skills for starting businesses, like resource mobilization, innovativeness and business planning.Urban and Naidoo (2012) conducted a study which indicated that to run a successful business, a manager needs a wide range of entrepreneurship skills among other skills, Since majority of SMEs are owner managed and owners are the providers of the resources to be used in business including finances, owner's lack of entrepreneurship skills can be a serious impediment to SMEs performance and to business success ( Adele etal.2011). The study therefore was conducted to determine the role of entrepreneur's competence on growth of small and medium enterprises in Kenya

\section{Objectives and Significance of the Study}

The purpose of the study was to determine the role of entrepreneur's competence on growth of small and medium enterprises in Kenya

\section{Specific Objectives}

The specific objectives of the study were to;

1. Establish entrepreneur's competence of SMEs in Bungoma County.

2. Examine the growth of small and medium enterprises in Bungoma county.

3. Determine the relationship between entrepreneur's competence and growth of small and medium enterprises 


\section{Null Hypothesis}

There is no significant relationship between entrepreneur's competence and growth of small and medium enterprises.

\section{LITERATURE REVIEW}

Musamali and Tarus (2013) argued that SMEs have consistently grown and generated interest from a wide range of stakeholders because they attempt to satisfy ostensibly the employment challenges, stimulate innovation and advancement and achieve sustainable development. Small Business Administration (2013) report indicated that more than half of new businesses worldwide do not survive beyond five years in United States of America. Over 70\% of new businesses survive for at least two years, but that drops to $50 \%$ by the five-year and $33 \%$ at 10 -year point, with just $25 \%$ lasting 15 years and more. Startups are key contributors to the innovation and growth dynamics of the European Union economy. However, many young enterprises fail in their early years and barriers to starting afresh dampen the potential gains that a strong startup culture could yield (European Union Annual Report, 2016). Studies on SMEs in Uganda indicate that $50 \%$ of SMEs do not live to see their first birthday. Those SMEs that survive beyond one year, less than $60 \%$ live to see their fifth birthday. These failures are fueled by many factors including lack of entrepreneurial skills, lack of capital, innovations and creativity and planning, limited market, frequent changes in commodity price, lack of access to timely market information and low bargaining power (Busingye, 2017). Kenyan SME sector is growing in importance; as SMEs are estimated to account for $20 \%$ of GDP and $80 \%$ of employment hence SMEs have the scope to catalyze further industrialization in Kenya (Phyllis, 2016). According to Mwangi etal. (2015) in Kenya SMEs are big contributors for economic growth and good financial performance of these entities is always very important and it is critically attributed with their economic contribution in one level or the other. According to Katua (2014) SMEs have been accepted as the core engine of economic growth and poverty eradication in the world. The government of Kenya has specified a number of key sectors that will prove instrumental in reaching its goals and mostly a middle income economy by 2030. In this plan, the government has aimed to create robust diversified and competitive SMEs and yet SMEs are failing. According to Janet and Ngugi (2014) most SMEs do not celebrate their third anniversary. The study of Bosire and Nzaramba (2013) in their findings concludes that development of entrepreneurial skills could serve as a measure for improving the self-reliant of startups and established entrepreneurs. Similarly, they found that entrepreneur's success depended on entrepreneurial skills for starting businesses, like resource mobilization, innovativeness and planning, as well as the survival and development in their early years. Undiayaundeye (2015) conducted a study among SMEs and identified a lack of entrepreneurial skills among graduates and thus, degenerate to failed entrepreneurial journey of business owners. Skills are the knowledge demonstrated through actions or a unique performance in certain situations. Skills are attained and developed through training Nevertheless, reaching sustainable business growth is a task that requires special skills (Zehra N.2016).

\section{Theoretical Review}

\section{Resource Based Theory.}

Barney in (1991) developed the resource based theory (RBT) to understand how organizations achieved sustainable competitive advantages (SCA). Barney argued that RBT competitive 
advantage occurred only when there was a situation of resource heterogeneity with different resources across firms with resources having; a strategic value to the firm to exploit opportunities or neutralize threats, resource were unique or rare to find amongst the current and potential competitors or difficult to acquire because the link between the capability or the achieved sustained competitive advantage was ambiguous or because it was socially complex, resource had to be non substitutable when competitors could not substitute the resource by another alternative resource to achieve the same results, resources to be imperfectly immutable where the resources could not be bought or sold on the market freely.

\section{Conceptual Framework}

Entrepreneurial Competence

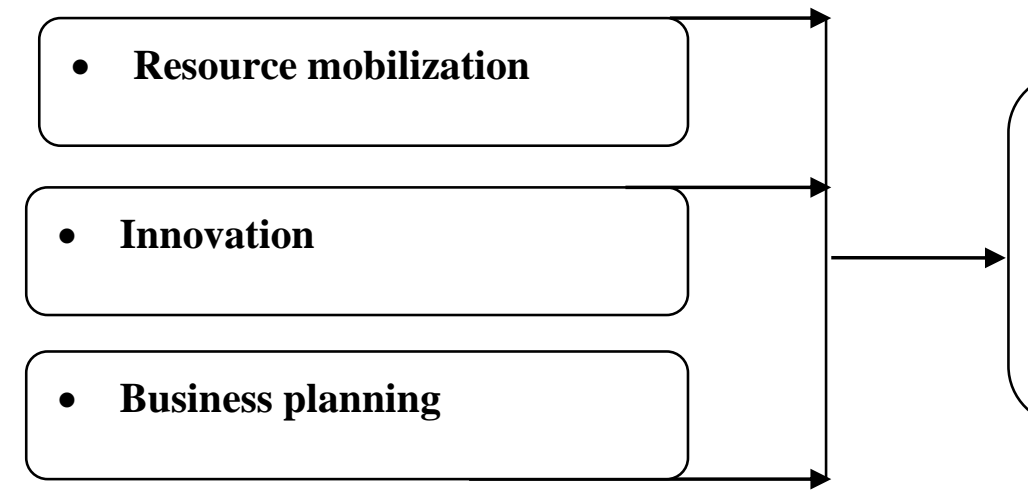

\section{Growth of MSEs}

- Return on investment

- Market share

- Profit

FIGURE 1.CONCEPTUAL FRAMEWORK

\section{METHODOLOGY}

\section{Research Design}

The study employed both descriptive, cross-sectional and correlation research designs with both qualitative and quantitative research approaches. Descriptive design was supported by Amin (2005) who argued that descriptive design is appropriate when the research objectives include portraying the characteristics of social or physical phenomena and determining the frequency of occurrence and determining the degree to which the variables are associated. The correlation was used to test the hypothesis in ascertaining the relationship among the variables of the study.

\section{Sample Size Determination}

The target population of study was 428 MSEs operating in Bungoma county. To determine the study sample size, the researcher used Krejcie and Morgan (1970) Table of Sample Determination to determine the sample size, in which a target population of 428 gave a sample size of 201.

Table 1

Target Population and Sample Size

\begin{tabular}{lll}
\hline Respondent category & Target Population & Sample Size \\
\hline Webuye town & 122 & 57 \\
Bungoma town & 306 & 144 \\
$\quad$ Totals & $\mathbf{4 2 8}$ & $\mathbf{2 0 1}$ \\
\hline
\end{tabular}




\section{RESULTS AND DISCUSSION}

The study analyzed demographic characteristics of respondents and the results are shown in Table 2

\begin{tabular}{|c|c|c|}
\hline \multicolumn{3}{|c|}{ Background Information of the Respondents } \\
\hline Demographic & Frequency & Percent \\
\hline \multicolumn{3}{|l|}{ Sex } \\
\hline Male & 94 & 56.6 \\
\hline Female & 72 & 43.4 \\
\hline \multicolumn{3}{|l|}{ Age } \\
\hline 18-25years & 14 & 8.4 \\
\hline $26-33$ years & 88 & 53.0 \\
\hline 34-41years & 51 & 30.7 \\
\hline 42 and above years & 13 & 7.8 \\
\hline \multicolumn{3}{|l|}{ Education level } \\
\hline No formal education & 15 & 9.0 \\
\hline Primary & 40 & 24.1 \\
\hline Secondary & 52 & 31.3 \\
\hline Diploma & 31 & 18.7 \\
\hline Bachelor Degree & 25 & 15.1 \\
\hline Masters & 3 & 1.8 \\
\hline \multicolumn{3}{|l|}{ Working experience } \\
\hline Less than 1 year & 13 & 7.8 \\
\hline $1-4$ years & 83 & 50.0 \\
\hline $5-8$ years & 52 & 31.3 \\
\hline 9 and above years & 18 & 10.8 \\
\hline
\end{tabular}

The results in Table 2 shows that $94(56.6 \%)$ of the respondents were male and $72(43.4 \%)$ were females. The findings implied that both male and females operated MSEs though males were dominant. The age of respondents were $14(8.4 \%)$ between $18-25$ years, $88(53 \%)$ between 26-33 years,51(30.7\%) between 34-41 years, and 13(7.8\%) were 42 and above years. The findings implied that most MSEs were youthful with the energy and vigor necessary to conduct business. The educational level of respondents was $15(9 \%)$ had no formal education, $40(24.1 \%)$ attained primary, 52(31.3\%) secondary, 31(18.7\%) diploma,25(15.1\%) bachelor degree while $3(1.8 \%)$ had masters. The implication of the findings was that majority of the respondents had the required literacy skills to respond to the questionnaires. A consideration of working experience indicated that $13(7.8 \%)$ had worked less than1 year, $83(50 \%)$ had worked between 2-4 years, 52(31.3\%) between 5-8 years, 18(10.8\%) worked above 9 years. The implication of the findings was that all the MSEs operators had adequate experience necessary to respond to the questionnaires.

The study had the objective of establishing the entrepreneur's competence of SMEs in Bungoma County. The results are shown in Table 3. 
Table 3

Entrepreneur's Competence

\begin{tabular}{llll}
\hline & Mean & Std. Deviation & Interpretation \\
\hline Resource Mobilization & 2.71 & .50 & High \\
Innovation & 2.12 & .47 & Low \\
Business Planning & 1.86 & .53 & Low \\
Grand Mean and SD & $\mathbf{2 . 2 3}$ & $\mathbf{0 . 5 0}$ & Low
\end{tabular}

Legend: $1.00-1.75$ very low; $1.76-2.50$ low; $2.51-3.25$ high; $3.26-4.00$ very high

The study results in Table 3 on establishing the entrepreneur's competence of SMEs in Bungoma County, indicated that there was high resource mobilization with a mean of 2.71 and SD of 0.50. The findings imply that SMEs are capable of mobilizing their own resources to run their enterprises. The findings are in agreement with Judith (2014) who notes that mobilization involves all activities meant to secure new and additional resources for your organization. It is the ability to gather and control the venture resources necessary to start, run and grow a business, and to manage them, efficiently and effectively use those resources for the intended purposes. The findings agree with Baumol (2010) and Villanueva, et al, (2012) that resource mobilization involves construction of resources by acquiring, transforming and utilizing them towards the exploitation of an entrepreneurial opportunity. The study results found low innovation among the SMEs with a mean of 2.12 and SD of 0.47. The implication of the results was that MSEs did not develop new ideas for their enterprises affecting their differentiation in a competitive market. The findings agree with Kraus \&Kauranen (2009) who indicated that creativity and innovation involves translating an idea or invention in to a good or service that creates value for which customer will pay. World Bank (2010) reported that entrepreneur's need an innovative skill which comprises of the cognitive skills like creative; behavioral skills like problem-solving skills to exploit opportunities. The study results showed business planning having a low mean of 1.86 and SD of 0.50 . The implication of the findings was that SMEs operated their enterprises without visible business plan which is a guiding document to entrepreneurs. The findings are in agreement with Shapiro (2010) indicated that planning is a vital aspect of strategic entrepreneurship because it offers firms flexibility in strategy implementation. The study results of Mbogo (2011) agree with current study findings that lack of planning, improper financing and poor management are the main causes of failure of small enterprises. Furthermore, Brian (2013) notes that ventures that are thoughtfully planned are more likely to succeed than those based primarily on guess work and hope. The planning process helps an entrepreneur identify exactly what needs to be accomplished to build the venture, and what human and financial resources are required to implement the plan. The overall grand mean for entrepreneur's competence was low with a mean of 2.23 with a SD of 0.50.The implications of the findings is that SMEs operators in Bungoma county lack the prerequisite entrepreneurial skills and knowledge affecting their growth save for resource mobilization.

The study had the objective of examining the growth of small and medium enterprises in Bungoma county. The findings are presented in Table 4. 
Table 4

Growth of SMEs

\begin{tabular}{llll}
\hline & Mean & Std. Deviation & Interpretation \\
\hline Return on Investment & 1.58 & .61 & Low \\
Market share & 2.10 & .52 & Low \\
Profits & 2.20 & .62 & Low \\
Grand mean and $S D$ & $\mathbf{1 . 9 6}$ & $\mathbf{. 5 8}$ & Low
\end{tabular}

Legend: $1.00-1.75$ very low; 1.76-2.50 low; 2.51-3.25 high; 3.26-4.00 very high

The study results in Table 4 on growth of SMEs in Bungoma County, indicated that there was low return on investment with a mean of 1.58 and SD of 0.61 . The implication of the findings was that SMEs realized minimal financial gains from their enterprises affecting their growth in the market. It was also found that market share had a low mean of 2.10 and SD of 0.52. The implication of the findings was that SMEs served the same markets which were not expanding affecting their income flow. The study results also indicated a low mean of 2.20 and SD of 0.62 on profits. The implication of the results was that SMEs generated meager revenues which did not sustain their growth. The overall grand mean for growth of SMEs was low with a mean of 1.96 and SD of 0.58 . The implication of the findings was that SMEs were performing dismally affecting their graduation/transition to the next higher level.

The study had the objective of determining the relationship between entrepreneur's competence and growth of small and medium enterprises. The results are presented in table 5.

Table 5

Relationship between Entrepreneur's Competence and Growth of Small and Medium Enterprises

\begin{tabular}{lll}
\hline & & Growth of SMEs \\
\hline Entrepreneur's competence & Pearson Correlation & $.341^{* *}$ \\
& Sig. (2-tailed) & .000 \\
& $\mathrm{~N}$ & 166 \\
\hline$* *$. Correlation is significant at the 0.01 level (2-tailed).
\end{tabular}

The results in Table 5 indicate that using Pearson correlation; it was found that there was a significant relationship between entrepreneur's competence and growth of SMEs with $p$. value 0.000. In reference to the findings of the study, the hypothesis of the study which stated that there is no significant relationship between entrepreneur's competence and growth of SMEs was rejected

The study also conducted a regression analysis to find the contribution of independent variables on growth of SMEs. The results are presented in Table 6.

Table 6

\begin{tabular}{|c|c|c|c|c|c|c|}
\hline \multicolumn{2}{|c|}{ Model } & \multicolumn{2}{|c|}{ Unstandardized Coefficients } & \multirow{2}{*}{$\begin{array}{l}\text { Standardized } \\
\text { Coefficients } \\
\text { Beta }\end{array}$} & \multirow[t]{2}{*}{$\mathrm{t}$} & \multirow[t]{2}{*}{ Sig. } \\
\hline & & $\mathrm{B}$ & Std. Error & & & \\
\hline \multirow[t]{4}{*}{1} & (Constant) & 1.317 & .213 & & 5.451 & .000 \\
\hline & Resource mobilization & -.051 & .070 & -.053 & -.270 & .404 \\
\hline & Innovation & .101 & .054 & .121 & 1.518 & .106 \\
\hline & Business planning & .301 & .055 & .387 & 5.102 & .000 \\
\hline
\end{tabular}

a. Dependent Variable: Competitiveness of SMEs 
Table 6 regression results showed that resource mobilization had t-value of -.270 and the significance level of 0.404 which is greater than the 0.05 therefore it is not significant. The implication of the finding is that resource mobilization does not significantly influence growth of SMEs. It was also found that innovation had a t-value of 1.518 and a significance level of 0.106 which is greater than 0.05 significance level. The results implied that innovation does not significantly influence growth of SMEs. The study results also showed that business planning had a t-value of 5.102 and a significance level of 0.000 which is less than 0.05 and thus significant. The implications of the findings is that business planning significantly contributes to growth of SMEs in Bungoma county.

\section{CONCLUTION AND RECCOMENDATIONS}

\section{Conclusion}

Based on the study findings, the researcher concludes that SMEs should embrace relevant competence skills to enable them operated growth-oriented enterprises which can graduate to higher levels thereby contributing to improved social and economic life of the operators and the nation at large.

\section{Recommendations}

The study makes the following recommendations;

1. The Owner managers of SMEs to attend trainings on resource mobilization and innovation so as to acquire adequate resource mobilization and innovation skills and differentiate themselves in the market place to grow their enterprises.

2. The government to put in place entrepreneurship policy to nurture business startups through mentorship, motivation and attitude change as they walk through entrepreneurship journey.

\section{References}

Abdul, O.E. (2018). Entrepreneurial skills and growth of small and medium enterprises (SMEs) A comparative analysis of Nigerian entrepreneurs and minority entrepreneurs in the UK. International Journal of Academics and Research in Business and Social Sciences, 8(5), 27-46.

Abor, J., \& Quartery A. (2010). Issues in SME development in Ghana and South Africa. International Research Journal of Finance and Economics, 3(39), 14-44.

Adele, A., Flore-Anne, M. (2011). Assessing financial literacy in 12 countries: an OECD/INFE international pilot exercise. Journal of Pension Economics and Finance, 10(4), 657-665.

Ahmad, N.H., Ramayah, T., Wilson, C., \& Kummerow, L. (2010). Is entrepreneurial competency and business success relationship contingent upon business environment? A study of Malaysian SMEs. International Journal of Entrepreneurial Behaviour \& Research, 16(3), 182-203.

Akhmad, N.H., Halim, H.A., \& Zainal, S.R.M. (2010). Is entrepreneurial competency the silver bullet for SME success in a development nation? International Business Management, 4(2), 67-75

ALShubiri, F. N. (2011). The Effect of Working Capital Practices on Risk Management: Evidence from Jordan. Global Journal of Business Research, 5(1), 39-54. 
Amin, D. (2005). Research Methods: Qualitative and Quantitative Approaches. Nairobi: Acts Press.

Amoro, J. E., Donnas, K. \&Bosma N. (2011). Global entrepreneurship monitor 2010 Global report. Global Entrepreneurship Research Association.

Anderson, A. (2009). Firm performance: An analysis from the theory of innovation, Australian Graduate School Entrepreneurship. Online, Retrieved May 29, 2019, http://www.swinburne.edu.au/lib/ir/onlineconferences/agse2009/000162.pdf

Andrew B., \& Nyaboga T. S. (2011). Knowledge management process capability operations. Strategy perspective. International Journal of Management and Information Systems, 3(4), 34-56.

Aquino, S. (2010). Accounting indicators for credit risk analysis of firms: a historical perspective. EconomiaAziendale Online, 1(2), 145-54.

Ar, I. M., \& Baki, B. (2011). Antecedents and performance impacts of product versus process innovation: Empirical evidence from SMEs located In Turkish Science and Technology Parks. European Journal of Innovation Management, 14(2), 172-206.

Bakar, L. J., \& Ahmad, H. (2010). Assessing the relationship between firm resources and product innovation performance. Business Process Management Journal, 16(3), 420435.

Barney, J. (1991). Firm Resources and Sustained Competitive Advantage. Journal of Management, 17, 99-120.

Baumol, W. (2010). The Micro theory of Innovative Entrepreneurship. Journal of Economic Literature, 48(3),769-774

Berger, A., Klapper F., \& Udell G. (2001). The ability of banks to lend to informationally opaque small businesses. Journal of Banking and Finance, 25, 2127-2167.

Bloom, N., \& Van Reenen, J., (2002). Patents, Real Options and Business Enterprise Growth. Economic Journal, 112, C97-C116.

Bosire, K., \& Nzaramba, (2013). Entrepreneurship skill development and growth of Small and medium enterprises in Rwanda. Journal of Information Technology and Business Management, 17(1).

Brian, S. (2013). The Effects of Technology in Society and Education. Education and Human Development Master's Theses.

Busingye, E. (2017). Towards enhancing business survival and growth rates in LDCs: An Exploratory Study of the drivers of business failure among SMEs in KampalaUganda. International Journal of Humanities and Social Science, 3(8).

Camison, C., \& Lopez, A.V. (2010). An examination of the relationship between manufacturing flexibility and firm performance: The mediating role of innovation, International Journal of Operations \& Production Management, 30(8), 853-878.

Carden, S. D., (2005). What Global Executives Think About Growth and Risk. Mckinsey Quarterly, (2), 16-25.

Chepkemoi, P. (2013). An Analysis of Effect of Capital Structure of Small and Medium Enterprises OnTheir Financial Performance: A Case Of Nakuru Town. School Of Business and Economics, Kabarak University. 
Chong, Y.L., Chan, T.S., Ooi, K.B., \& Sim, J.J. (2011). Can Malaysian Firms Improve Organizational/Innovation Performance Via SCM. Industrial Management and Data System, 111(3), 410-431.

Danisman, A., \& Erkocaoglan, E. (2007). Enteprenuership and Business Enterprise Growth: A Research Study on Istanbul Stock Exchange Business Enterprises. Iktisat Is LetmeVeFinans, 22(260),80-101.

Dess, G. G., \& Lumpkin, G. T. (2005). The Role of Entrepreneurial Orientation In Stimulating Effective Entrepreneurship. Academy of Management Executive, 19(1), 147-156.

Donnas, J., Kelley, Niel, B.,\&Global Entrepreneurship. (2011). Global entrepreneurship monitor 2010 global report global entrepreneurship research association (GEKA)

Eggers, F., Kraus, S., Hughes, M., Laraway, S., \&Syncerski, S. (2013). Implications of Customer and Entrepreneurial Orientations for Sme Growth. Management Decision, 51(3), 524-546.

Ernest \& Young, (2013). Major environment constraints on growth of micro and small enterprises in Uganda: A survey of selected micro and small enterprises in Mbarara Municipality. International Journal of Cooperative Studies, 2(1).

European Union (2016). Annual Report on SMEs. Focus on self-employment

Geroski, P. A. (2000). The Growth Of Business Enterprises In Theory And Practice, Pp. 168186 In:Foss,N., Mahnke, V., (Eds.), Competence, Governance And Entrepreneurship, Oxford University Press, Oxford

Gibson, B., \& Cassar, G. (2005). Longitudinal analysis of relationships between planning and performance in small firms. Small Business Economics, 25, 207-222.

Githire, C., \& Muturi, W. (2015). Effects of Capital Structure on Financial Performance of Firms in Kenya: Evidence from Firms Listed at The Nairobi Securities Exchange. International Journal of Economics, Commerce and Management, 3(4), 1-10.

Glaister, K. W., Dincer, O., Tatoglu, E., Demirbag, M., \&Zaim, S. (2008). A causal analysis of formal strategic planning and firm performance: Evidence from an emerging country. Management Decision, 46(3), 365-391.

Janet, M., \& Ngugi, K. (2014). Influence of Entrepreneurial Marketing on The Growth of Smes In Kiambu Town-CBD, Kenya. European Journal of Business Management, 1 (11), 361-377.

Jarko, F., \& Christa, H. (2009). Default rates in the loan market for SMEs: Evidence from Slovakia. Accessed 23 $3^{\text {rd }}$ May 2019 from http://www.cesifogroup.de/DocDL/IfoWorkingPaper-72

Judith, B., \& Stephen, W. (2014). Doing your research project. A guide for first-time researchers, $\left(6^{\text {th }}\right.$ Ed., $)$, Berkshire, UK, McGraw-Hill Education.

Freeman, R.E. (1984). Strategic management:A stakeholder approach. Boston: Pitman.

Harrison, J.S., Bosse, D.A., \& Phillips, R.A. (2010). Managing for stakeholders, stakeholder utility functions and competitive advantage. Strategic Management Journal, 31(1), $58-74$.

Jones, T.M. (1995). Instrumental stakeholder theory: A synthesis of ethics and economics. Academy of Management Review, 20, 404-437. 
Katua, N. T. (2014). Role of SMEs in employment creation and economic growth in selected countries. International Journal of Education and Research, 2, 461-472.

Kenya National Bureau of Statistics (2016). Small and Medium Enterprises survey

Kerosi, J.B., \& Kayisime, N. (2013). Entrepreneurship skill development and growth of small and medium enterprises in Rwanda (case study "CAPLAKI)

Kerosi, J. B., \& Kayisime, N. (2013). Entrepreneurship skills development and growth of small and medium enterprises in Rwanda. A case study of APLAKI: 2007-2011.

Kinyua, A. N. (2014). Factors affecting the performance of small and medium enterprises in the Jua Kali Sector in Nakuru Town, Kenya Egerton University Nakuru.

Kothari, C.R. (2004). Research Methodology: Methods and Techniques (2 ${ }^{\text {nd }}$ Ed.,), New Age International Publishers, New Delhi

Kraus, S., \& Kauranen, I. (2009). Strategic Management and Entrepreneurship: Friends or Foes? International Journal of Business Science and Applied Management, 4(1), 3750.

Kraus, S., Harms, R., \& Schwarz, E. J. (2006). Strategic planning in smaller enterprises-new empirical findings. Management Research News, 29(6), 334-344.

Kreiser, P. M., \& Davis, J. (2010). Eo And Firm Performance: The Unique Impact Of Innovativeness, Pro-Activeness And Risk-Taking. Journal of Small Business and Entrepreneurship, 23(1), 39-51.

Kreiser, P. M., Marino, L. D., Kuratko, D. F., \& Weaver, K. M. (2013). Disaggregating entrepreneurial orientation: the non-linear impact of innovativeness, proactiveness and risk-taking on SME performance. Small Business Economics, 40(2), 273-291.

Luweero District Local Government statistical Abstract- Uganda Bureau of Statistics (2017).

Man, M.M.K., \& Wafa, S.A. (2008). Distinctive capabilities and the performance of small and medium-size enterprises (SMEs) in Malaysia. International Business \& Economics Research Journal, 7(6), 45-59

Manos, R., Murinde, V., \& Green, C. J. (2012). Dividend policy and business groups: Evidence from Indian firms. International Review of Economics \& Finance, 21(1), 4256.

Mbogo, M. (2011). Influence of managerial accounting skills on SME's on the success and growth of small and medium enterprises in Kenya. Journal of Language, Technology and Entrepreneurship in Africa, 3(1), 15

Morone, P., \& Testa, G. (2008). Firms growth, size and innovation an investigation into: The Italian manufacturing sector, Economics of Innovation and New Technology, Taylor and Francis Journals, 17(4), 311-329.

Mugo, W. L. (2012). Factors affecting entrepreneurs' performance in Kenya: A case of Nairobi women groups in the Central Business District (Unpublished Master's thesis), University of Nairobi, 2012

Mukoma, F.K., \& Masini, D.O. (2015). Effects of microfinance institutions products on financial performance of small and medium enterprises in Machakos town Kenya (Unpublished MBA project), University of Nairobi.

Musamali, M.M., \& Tarus, D. K. (2013). Does firm profile influence financial access among small and medium enterprises in Kenya? Asian Economic and Financial Review,3(6) 714-723. 
Mwangi, M., \& Murigu, J. W. (2015). The determinants of financial performance in general insurance companies in Kenya. European Scientific Journal, ESJ, 11(1).

Nazir, M. S., \& Afza, T. (2009). Impact of aggressive working capital management policy on firms' profitability. The IUP Journal of Applied Finance, 15.

Nichter, S., \& Goldmark, L. (2009). Small Firm Growth in Developing Countries. World Development, 37(9), 1453-1464.

Nimalathasan, B. (2008). A relationship between owner-managers characteristic and business performance. Les ET Scientia International Journal, XV(1).

Ogut, M. (2010). Bank explosion a great chance for MFIs. Daily Monitor, Tuesday, January26.

Pangarkar, N. (2008). Internationalization and performance of small-and-medium sized

Pedro et al. (2004). Effects of Working Capital Management on SME Profitability University of Murcia investment. American Economic Review, 48, 261-295.

Phyllis, P. (2016). The role of finance in Kenyan manufacturing. scoping paper.

Private Sector Foundation Uganda (PSFU) 2013 Journal report.

Rivaud-Danset, D., Dubocage, E., \& Salais, R. (2001). Comparison between the financial structure of SMES and that of large enterprises (LES) using the BACH database. European Economy-Economic Papers.

Sajilan, S., Shehnaz, T., \& Adeyinka, S. (2016). A conceptual framework of the impact entrepreneurial competences on small and medium enterprises business performance in Malaysian hospitality and tourism industry.

Shah, S. (2010). Financing the Current Assets: Approach Followed by Small and Medium Enterprises in Pakistan. Interdisciplinary Journal of Contemporary Research in Business, 2(7), 10.

Shehnaz, T., Huhaib, H., \& Qureshi. (2018). Impact of network competence on firm's performance among Chinese and Indian entrepreneurs: a multigroup analysis: International Journal of Entrepreneurship.

Street, C.T., \& Cameron, A.F. (2007). External relationships and the small business: A review of small business alliance and network research, Journal of Small Business Management, 45(2).

Suklev, B., \& Debarliev, S. (2012). Strategic planning effectiveness comparative analysis of the Macedonian context. Economic and Business Review, 14(1), 63-93.

Sulaiman, E. D. M., Yusoff, Y. M., \& Chelliah, S. (2010). Internationalization and performance: small and medium enterprises (SMEs) in Malaysia. International Journal of Business and Management, 5(6), 27-37.

Tavitiyaman, P., Zhang, H. Q., \&Qu, H. (2012). The effect of competitive strategies and organizational structure on hotel performance, International Journal of Contemporary Hospitality Management,24(1), 140-159.

Tippins, M. J., \& Sohi, R. S. (2003). It Competency and Firm Performance: is organizational learning a missing link? Strategic Management Journal, 24(8), 745-761.

Tushabomwe, K. C. (2006). Causes of small business failure in Uganda. A case study from Bushenyiand Mbarara Towns (Unpublished thesis), Makerere University

UBOS. (2016). Poverty Projections Statistical Abstract. Kampala Journal of Business Venturing, 24, 197-205. http://dx.doi.org/10.1016/J.Jbusvent.2018.01.007 
Uganda Registration Services Bureau-URSB, (2014). Report on The Uganda Business Register, Annual Report 2013/2014.

Undiyandeye, F.A. (2015). Entrepreneurship skills acquisition and the benefits amongst the under graduate students in Nigeria. European Journal of Social Sciences Education and Research, 5(3) 123-145.

Urban, B., \& Naidoo, R. (2012). Business sustainability: empirical evidence on operational skills in SMEs in South Africa. Journal of Small Business and Enterprise Development, 19(1),146-163.

Varis, M., \& Littunen, H. (2010). Types of innovation, sources of information and performance in entrepreneurial SMEs. European Journal of Innovation Management, 13(2), 128-154.

Wang, Y., \& Poutziouris, P. (2010). Leadership styles, management systems and growth: empirical evidence from UK owner-managed SMEs. Journal of Enterprising Culture (jec), 18(3), 331-54.

West, G., \& Terry, W. N. (2009). The impact of knowledge resource on new venture performance. Journal of Small Business Management, 8(5), 78-99.

Wijetunge, W. A. D. S., \& Pushpakumari, M. D. (2014). Entrepreneurial orientation and business performance of small and medium scale enterprises of Western Province in Sri Lanka. Kelaniya Journal of Management, 2(2), 51-67.

Wiklund, J., \& Shepherd, D. (2005). Entrepreneurial Orientation and Small Firm Performance: A Configurational Approach. Journal of Business Venturing, 20, 71-91.

World Bank. (2010). International finance corporation (IFC) annual report 2010 where innovation meets impact (Vol.2): IFC financial, projects and portfolio 2010 (English). Washington DC; World Bank. http://documents.world bank.org/curated/en/970081468331866551/ifc-financial-project

World Bank. (2010). International finance corporation (IFC) annual report. Where innovation meets impact vol. 2.IFC financials, projects and portfolio. Washington DC. World Bank.

Zehra, N. (2016). Training \& Development Barometer for Effective Transformation of Organizational Commitment and Overall Performance in Banking Sectors of KPK, Pakistan: Qualitative study of Workforce of Bank of Khyber. International Journal of Academic Research in Business and Social Sciences, 6(6),246-267.

Zoysa, A. D., \& Herath, S.K. (2007). The impact of owner/managers' mentality on financial performance of SMEs in Japan: An empirical investigation. Journal of Management Development, 26(7), 652-666.

\section{Acknowledgements}

I acknowledge the support I received from my Dean Dr. Kadian Wanyonyi, Chairman of department Dr. Munir Manini and Dr Sylvia who supported my endeavors.

\section{Conflict of Interest Statement}

No conflict of interest has been declared by the authors. 